\title{
Assessment of soil organic carbon stock in different agro-ecological land use of Ri-Bhoi district, Meghalaya
}

Kabir Debbarma and Naorem Janaki Singh

Received : 06.01.2020; Revised : 05.05.2020; Accepted : 22.05.2020

MEMBERS OF RESEARCH FORUM:

Corresponding author :

Kabir Debbarma, College of Post

Graduate Studies in Agricultural

Sciences (Central Agricultural

Univeristy), Umiam (Meghalaya)

India

Email: kabirdb90@gmail.com

Co-authors :

Naorem Janaki Singh, North

Eastern Space Applications Centre,

Umiam (Meghalaya) India

\section{Summary}

A study was carried out in Ri-Bhoi district of Meghalaya. The studies have focused on organic carbon (C) stocks of soils because of increases in atmospheric carbon dioxide $\left(\mathrm{CO}_{2}\right)$. Six agro-ecological land use were intersect with 7 slopes to generate soil sample location. Three locations have been selected for each strata to determine the average carbon stock. The mean organic soil organic carbon ranged between 1.53 per cent to 2.43 per cent with maximum in S1T2 (2.42\%) followed by S2T2 (2.38\%), S2AG2 (2.20\%) and minimum in S7OS1 (1.53\%) followed by S7OS2 (1.56\%) and S6OS1 (1.60\%). The mean BD ranged between 1.22 to $1.42 \mathrm{~g} / \mathrm{cm}^{3}$ with maximum in S7OS2 $\left(1.42 \mathrm{~g} / \mathrm{cm}^{3}\right)$ and minimum in S1T2 $\left(1.22 \mathrm{~g} / \mathrm{cm}^{-3}\right)$ and S3T2 $\left(1.22 \mathrm{~g} / \mathrm{cm}^{-3}\right)$. The mean SOC stock ranges from $44.41 \mathrm{Mg} \mathrm{ha}^{-1}$ to $32.5 \mathrm{Mg} \mathrm{ha}^{-1}$ with mean SOC stock content was found maximum in S1T2 (44.41 $\mathrm{Mg} \mathrm{ha}^{-1}$ ) followed by S2T2 (43.49 Mg $\mathrm{ha}^{-1}$ ) and minimum in S7OS1 (32.51 $\mathrm{Mg} \mathrm{ha}^{-1}$ ) followed by S7OS2 (33.1 Mg ha' $)$.

Key words : Ri-Bhoi, Organic carbon, Agro-ecological, Land use, Carbon stock, Strata

How to cite this article : Debbarma, Kabir and Singh, Naorem Janaki (2020). Assessment of soil organic carbon stock in different agro-ecological land use of Ri-Bhoi district, Meghalaya. Asian J. Soil Sci., 15 (1) : 27-33 : DOI : 10.15740/HAS/AJSS/15.1/27-33. Copyright@ 2020: Hind Agri-Horticultural Society. 